Gut, 1987, 28, 446-450

\title{
Intestinal involvement in progressive systemic sclerosis detected by increased unconjugated serum bile acids
}

\author{
F STELLAARD, T SAUERBRUCH, CH LUDERSCHMIDT, B LEISNER, \\ AND G PAUMGARTNER
}

From the Department of Medicine II, Klinikum Grosshadern, Department of Dermatology and Department of Radiology, University of Munich, Munich, FRG

SUMMARY In patients with progressive systemic sclerosis, impaired motor function of the small intestine may lead to bacterial overgrowth causing diarrhoea, steatorrhoea and malabsorption. As unconjugated serum bile acids have been proposed as markers for small bowel bacterial overgrowth, we studied individual unconjugated serum bile acids in 36 patients with progressive systemic sclerosis. These patients had significantly higher serum concentrations of unconjugated cholic acid (median 0.18; range $0.05-30.75 v 0.09 ; 0.01-0.19 \mu \mathrm{mol} / \mathrm{l}, \mathrm{p}<0.001$ ) and chenodeoxycholic acid $(0 \cdot 10 ; 0 \cdot 01-6 \cdot 83 v 0 \cdot 04 ; 0 \cdot 01-0.39 \mu \mathrm{mol} / \mathrm{l}, \mathrm{p}<0 \cdot 025)$ than healthy controls $(\mathrm{n}=16)$. This difference was mainly due to patients with diarrhoea $(n=10)$, who had significantly higher concentrations of unconjugated serum bile acids than patients with normal bowel habit (cholic acid median $0.55 \vee 0.16 \mu \mathrm{mol} / \mathrm{l}, \mathrm{p}<0.001 ;$ chenodeoxycholic acid $0.75 v 0.07 \mu \mathrm{mol} / \mathrm{l} ; \mathrm{p}<0.005)$. All patients with raised unconjugated serum bile acids had oesophageal motility disorders. These results confirm a relationship between motility disorders and bacterial overgrowth in patients with progressive systemic sclerosis.

Progressive systemic sclerosis is a multisystem disorder with frequent involvement of the gastrointestinal tract. The oesophagus is affected with or without symptoms in over $50 \%$ of the patients. ${ }^{1-4}$ Radiological small bowel abnormalities have been reported in about half of the patients with progressive systemic sclerosis. ${ }^{15}$ The main findings are hypomotility, dilatation of the duodenum, segmental dilatation of other bowel loops and pseudodiverticula. ${ }^{1-7}$ In patients with radiological evidence of small bowel involvement an abnormal fasting motor activity has been shown. ${ }^{x}$ Segmental dilatation and impaired motor function of the small intestine may lead to bacterial overgrowth causing diarrhoea,

Address for correspondence: Dr F Stellaard, Dept of Medicine II. Klinikum Grosshadern. Marchioninistr. 15. D-800(1) Munich 70, Federal Republic of Giermany

Received for publication 4 August, 1986. steatorrhoea, and malabsorption in patients with progressive systemic sclerosis. ${ }^{9-12}$

Enteric bacteria rapidly hydrolyse glycine and taurine conjugates of cholic acid, chenodeoxycholic acid, and deoxycholic acid. ${ }^{1:-15}$ Deconjugated bile acids are rapidly absorbed from the small intestine and spill over from the enterohepatic circulation into the blood stream. ${ }^{16-18}$ Thus, a sensitive method for the determination of unconjugated serum bile acids should permit detection of patients with bacterial overgrowth and progressive systemic sclerosis. We are not aware of a systematic evaluation of serum bile acids in patients with progressive systemic sclerosis. Therefore, we determined conjugated and unconjugated serum bile acids in patients with progressive systemic sclerosis. The findings in patients with and without history of diarrhoea as well as with and without advanced oesophageal involvement assessed by functional scintigraphy were compared. 


\section{Methods}

PATIENTS

Serum of 36 consecutive patients with progressive systemic sclerosis and normal liver tests (alkaline phosphatase, aminotransferases, bilirubin, and total serum conjugated bile acids) was analysed. The group consisted of nine men and 27 women with a mean age of 51 years. All patients had a history of Raynaud's phenomenon and evidence of cutaneous involvement with scleroderma (sclerosis, sclerodactyly and digital pitting scars). The patients had a history of disease between one year and 19 years (mean eight $\pm S D$ five years). All but one patient revealed antinuclear antibodies. None of the patients received antibiotics at least three weeks before blood sampling. Ten of the patients had diarrhoea defined as more than four loose stools per day over a period of the last three months. In 14 patients radiological studies of the upper intestinal tract were carried out. Eight of those patients showed dilated small bowel loops and/or a markedly decreased peristalsis. Sixteen healthy volunteers (six men, 10 women comparable in age, mean 55 years) served as controls. Blood was drawn two to three hours after breakfast in all subjects and centrifuged. Serum was stored at $-20^{\circ} \mathrm{C}$. In addition, the progressive systemic sclerosis patients underwent oesophageal functional scintigraphy within six months before blood sampling.

DETERMINATION OF SERUM BILE ACIDS

Two millilitres of serum were extracted on Bond Elut $\mathrm{C}_{18}$ cartridges. ${ }^{1920}$ The bile acids were eluted with $6 \mathrm{ml} \mathrm{75 \%} \mathrm{methanol,} \mathrm{passed} \mathrm{through} \mathrm{a} \mathrm{SP-Sephadex}$ column $\left(\mathrm{H}^{+}\right.$-form, $\left.4.5 \mathrm{~cm} \times 8 \mathrm{~mm}\right)$ and bound to a DEAP-LH-20 column $(4.5 \mathrm{~cm} \times 8 \mathrm{~mm})$. According to Setchell $e t a l^{\prime \prime}$ the unconjugated bile acids were eluted with $6.5 \mathrm{ml} 0.1 \mathrm{~mol} / \mathrm{l}$ acetic acid in $72 \%$ ethanol ( $\mathrm{pH} \mathrm{4 \cdot 0),} \mathrm{the} \mathrm{conjugated} \mathrm{fraction} \mathrm{with} 6.5 \mathrm{ml} 0 \cdot 15$ $\mathrm{mol} / \mathrm{l}$ acetic acid in $72 \%$ ethanol $(\mathrm{pH} 6.4)$ and the sulfated conjugated fraction with $10 \mathrm{ml} 0.3 \mathrm{~mol} / \mathrm{l}$ acetic acid in $72 \%$ ethanol ( $\mathrm{pH} \mathrm{9 \cdot 6).} \mathrm{The} \mathrm{last} \mathrm{two}$ fractions were pooled. After cleaning the unconjugated fraction and the pooled conjugated fractions by extracting the eluate with three volumes of nhexane after acidification to $\mathrm{pH} 4$, the solutions were evaporated to dryness. The unconjugated fraction was directly methylated and trimethylsilylated. ${ }^{21}$ The pooled conjugated fraction was solvolysed ${ }^{22}$ and deconjugated enzymatically. ${ }^{23}$ Thereafter the deconjugated bile acids were extracted on Lipidex $1000,{ }^{21}$ methylated and trimethylsilylated. The methyl ester TMS ether derivatives were dissolved in $25 \mu \mathrm{l}$ isooctane and 1-2 $\mu$ l were analysed by capillary gas liquid chromatography/electron impact mass spectrometry, and selected ion monitoring. A $25 \mathrm{~m} \times(0.32 \mathrm{~mm}$ fused silica capillary OV-1701 column $^{211} 24$ (CP Sil 19 CB, Chrompack, Middelburg, The Netherlands) was directly inserted into a Finnigan 4000 mass spectrometer. Samples were introduced by cold on-column injection and temperature programming. ${ }^{21}$ Quantification was carried out using $11,12^{-2} \mathrm{H}_{2}$-chenodeoxycholic acid as an internal standard..$^{25}$

OESOPHAGEAL FUNCTIONAL SCINTIGRAPHY Oesophageal transit was measured as described previously. ${ }^{26}$ After the patient had swallowed 10 $\mathrm{MBq}^{4 \% \mathrm{~m}} \mathrm{Tc}-\mathrm{DTPA}$ in $15 \mathrm{ml}$ water in supine position, counts were stored in $1 \mathrm{sec}$ frames and processed with a region of interest including the whole oesophagus. The time activity histogram was subsequently transformed into a clearance curve. The value established for healthy subjects in our department was $91 \pm 4.8 \%$ of the maximal oesophageal radioactivity cleared within 10 seconds.

\section{STATISTICAL ANALYSIS}

The data for the different groups of patients and the controls are expressed as median and range. For statistical evaluation of differences between the medians, the Mann-Whitney rank test for unequal group sizes was used. The upper limit of the reference values was defined as mean +2 standard deviations of the healthy controls. A p value less than ().05 (one tailed) was considered statistically significant.

\section{Results}

Whereas serum concentrations of conjugated bile acids were similar in progressive systemic sclerosis patients $(2 \cdot 16 ; 0 \cdot 50-4 \cdot 26 \mathrm{~mol} / \mathrm{l})$ and controls $(1 \cdot 47$; $0.45-5.22 \mu \mathrm{mol} / \mathrm{l})$, the unconjugated bile acids were significantly raised in progressive systemic sclerosis patients (Table). This rise was mainly caused by unconjugated cholic acid and unconjugated chenodeoxycholic acid. Unconjugated deoxycholic acid was not significantly raised.

Raised unconjugated serum bile acids were only found in patients with impaired oesophageal clear-

Table Unconjugated serum bile acids ( $\mu m o l / l)$ in PSS patients and controls (median and range)

\begin{tabular}{|c|c|c|c|}
\hline & $\begin{array}{l}\text { PSS patients } \\
(n=36)\end{array}$ & $\begin{array}{l}\text { Controls } \\
(n=16)\end{array}$ & \\
\hline Cholic acid & $0 \cdot 18(0 \cdot 05-3() \cdot 75)$ & $0.09(0.01-0.19)$ & $p<0) \cdot(x) 1$ \\
\hline $\begin{array}{l}\text { Chenodeoxy- } \\
\text { cholic acid }\end{array}$ & $(0 \cdot 10(0 \cdot() 1-6 \cdot 83)$ & $0.04(0) \cdot(01-(0.39)$ & $\mathrm{p}<0.025$ \\
\hline Deoxycholic acid & $0.34(0 \cdot 10-6 \cdot 37)$ & $(0 \cdot 28(0 \cdot 01-1 \cdot 16)$ & ns \\
\hline Total & $(0.74(0 \cdot 23-42 \cdot 81)$ & $0 \cdot 39(0 \cdot 0) 3-1 \cdot 36)$ & $p<0) \cdot(0) 5$ \\
\hline
\end{tabular}


ance (values below $80 \%$ ) as shown for unconjugated cholic acid in Figure 1. Rises of unconjugated serum bile acids were most pronounced in patients with low oesophageal clearance.

In patients with diarrhoea, the levels of unconjugated serum bile acids were significantly higher $(\mathrm{p}<0.001)$ than in patients without diarrhoea $(1.68 \mathrm{v}$ $0.51 \mu \mathrm{mol} / \mathrm{l} ; \mathrm{p}<0.001)$. Again, this difference was caused mainly by unconjugated cholic acid $(0.55 v$ $0.16 \mu \mathrm{mol} / \mathrm{l} ; \mathrm{p}<0.001)$ and chenodeoxycholic acid $(0.75 v 0.07 \mu \mathrm{mol} / \mathrm{l} ; \mathrm{p}<0.05)$. Of the 10 patients with diarrhoea, eight had raised unconjugated cholic acid $(>0.23 \mu \mathrm{mol} / \mathrm{l})$ and six had raised concentrations of unconjugated chenodeoxycholic acid $(>0.28 \mu \mathrm{mol} / \mathrm{l})$ (Fig. 2).

Of the 26 patients without diarrhoea, only five had raised concentrations of unconjugated cholic acid or chenodeoxycholic acid (Fig. 2). Of the eight patients in whom dilated loops and/or a decreased peristalsis were detected radiologically, seven had raised serum concentrations of unconjugated cholic acid. All six

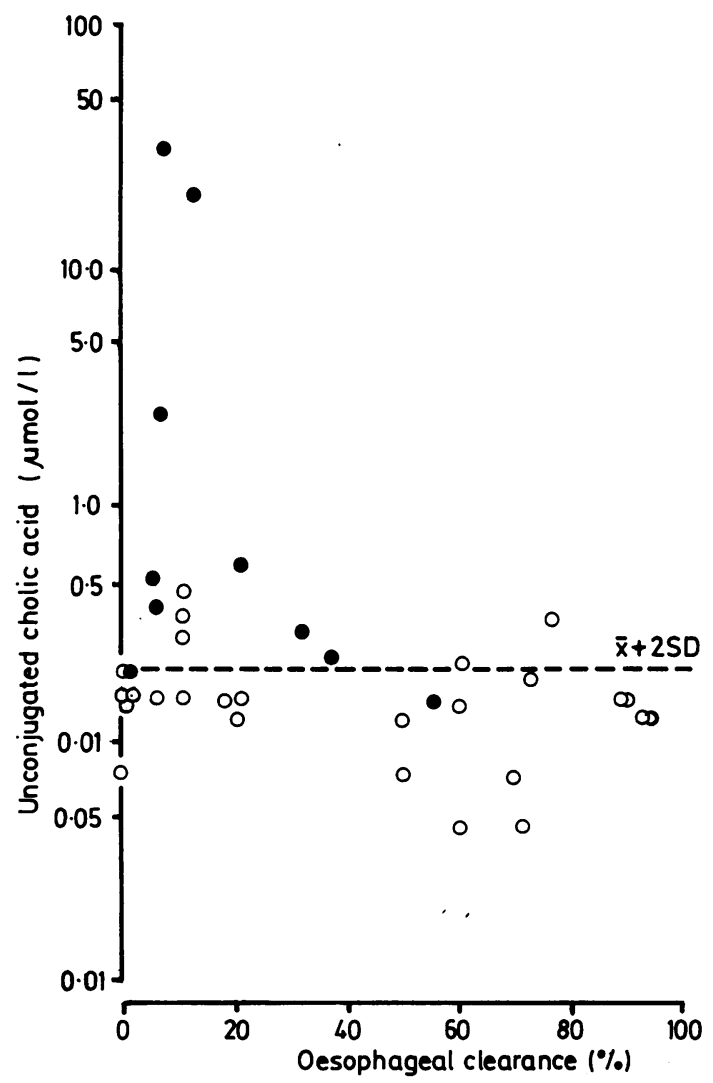

Fig. 1 Serum concentrations of unconjugated cholic acid and oesophageal clearance of $10 \mathrm{MB} \mathrm{q}^{4 \mathrm{~m}} \mathrm{Tc}-D T P A$ in progressive systemic sclerosis (PSS) patients with $(\mathbf{O})$ and without $(\bigcirc)$ diarrhoea. patients who showed no radiological evidence of an altered intestinal function, had normal concentrations of unconjugated cholic acid in the serum.

\section{Discussion}

In patients with progressive systemic sclerosis, defects of small bowel motility may lead to stasis of intestinal contents and may favour bacterial overgrowth of the upper small intestine by anaerobic bacteria such as Bacteroides fragilis or bifido bacterium. It has been shown that these bacteria are able to deconjugate bile acids. ${ }^{27}$ Deconjugated bile acids can easily pass into the portal blood by passive diffusion. Because serum bile acids reflect the bile acid pattern of the portal blood, ${ }^{2 \mathrm{x}}$ it may be expected that bacterial overgrowth leads to rises in unconjugated bile acids in peripheral blood. ${ }^{29}$ Indeed, the rise in unconjugated bile acids in the serum of our patients with progressive systemic sclerosis may be due to this mechanism.

Further analysis of the data showed that a rise in unconjugated bile acids in serum was mainly restricted to patients with signs of motility disorders such as impaired oesophageal clearance and diarrhoea. Diarrhoea in these patients may not only be related to the motility disorder but also to the properties of deconjugated bile acids. Deconjugated bile acids are poor micelle formers ${ }^{12}$ and in addition may exert toxic effects on the enterocytes. ${ }^{31-32}$ Our findings confirm earlier observations ${ }^{101133}$ stressing deconjugation of bile acids by bacterial overgrowth as an important pathogenetic factor for malnutrition and diarrhoea in patients with progressive systemic sclerosis.

Further prospective studies are warranted to investigate the clinical value of serum bile acid determinations in the evaluation of patients with progressive systemic sclerosis. Especially, a comparison of unconjugated serum bile acids with the $1-{ }^{14} \mathrm{C}$ glycocholate breath test ${ }^{3+}$ appears desirable. In a separate study (in preparation) of patients with bacterial overgrowth of the small intestine not caused by progressive systemic sclerosis, we have found agreement between a pathological breath test and raised concentrations of unconjugated primary bile acids in serum.

Our results suggest a relationship between motility disorders and bacterial overgrowth in patients with progressive systemic sclerosis. Unconjugated bile acids in serum were raised in about one third of patients with impaired oesophageal clearance and in most of those with diarrhoea.

\section{References}

1 Poirier TJ, Rankin GB. Gastrointestinal manifestations 


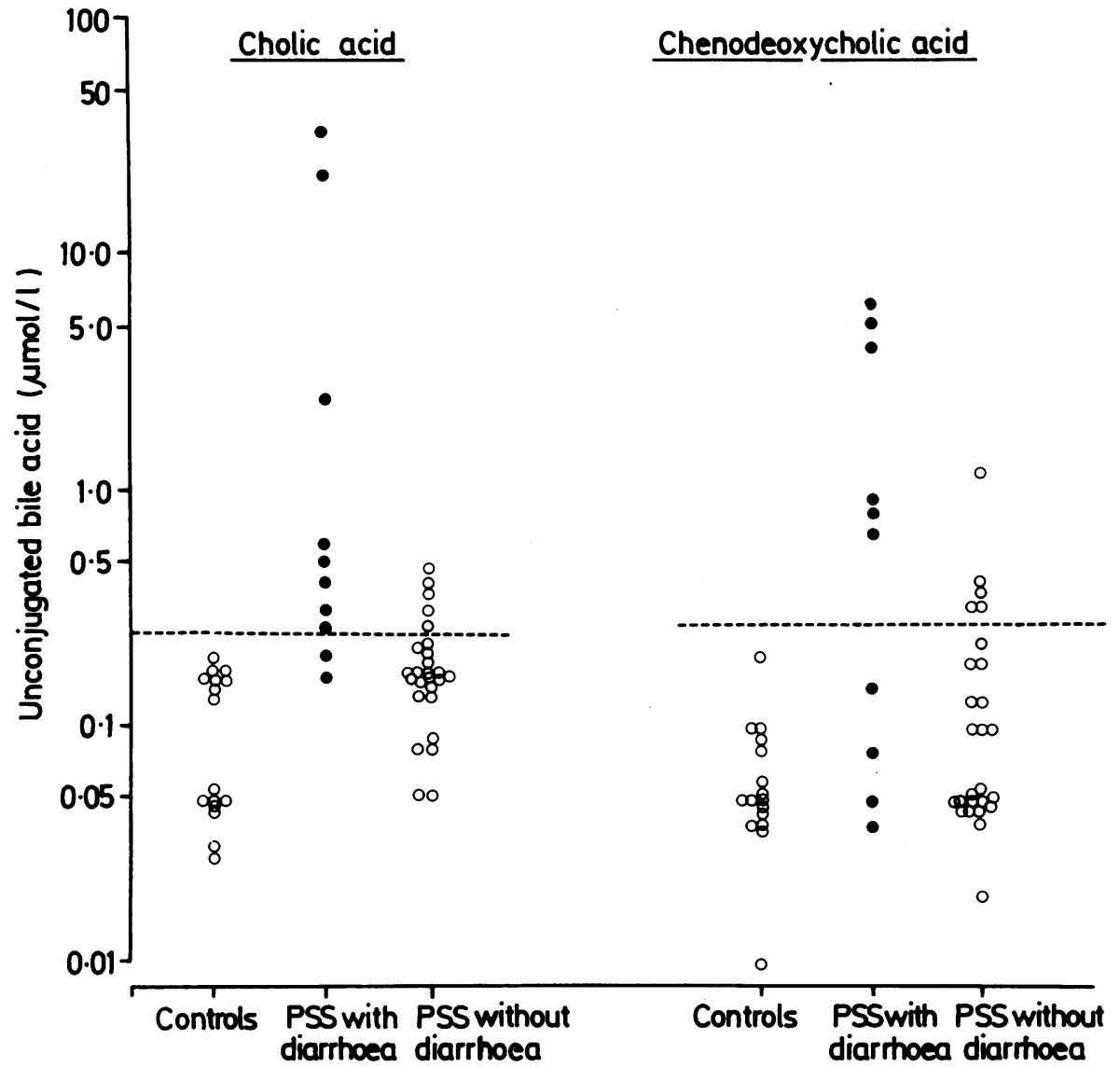

Fig. 2 Serum levels of unconjugated cholic acid and chenodeoxycholic acid in healthy controls and PSS patients with (O) and without $(\mathrm{O})$ diarrhoea. The dotted lines represent the mean $\pm 2 S D$ of healthy controls.

of progressive systemic scleroderma based on a review of 364 cases. Am J Gastroenterol 1972; 58: 30-44.

2 Garrett JM, Winkelmann RK, Schlegel JF, Code ChF. Esophageal deterioration in scleroderma. Mayo Clinic Proc 1971; 46: 92-6.

3 Luderschmidt Ch, Leisner B, König G. Die Ösophagusfunktionsscintigraphie als Parameter für die interne Manifestation bei progressiver Sklerodermie. In: Holzmann Altmeyer, ed. Dermatologie und Nuklearmedizin. Heidelberg: Springer Verlag, 1985: 315-21.

4 Schneider HA, Yonker RA, Longley S, Katz P, Mathias J, Panush RS. Scleroderma esophagus: a nonspecific entity. Ann Intern Med 1984; 100: 848-50.

5 Bluestone R, Macmahon M, Dawson JM. Systemic sclerosis and small bowel involvement. Gut 1969; 10: 185-93.

6 Cohen S, Laufer J, Snape WJ, Shiau YF, Levine GM, Jimenez $S$. The gastrointestinal manifestations of scleroderma: pathogenesis and management. Gastroenterology 1980; 79: 155-66.

7 Peachy RDG, Craemer B, Pierce JW. Sclerodermatous involvement of the stomach and the small and large bowel. Gut 1969; 10: 285-92.
8 Rees WDW, Leigh RJ, Christofides ND, Bloom SR, Turnberg LA. Interdigestive motor activity in patients with systemic sclerosis. Gastroenterology 1982; 83: 575-80.

9 Vantrappen G, Janssens J, Hellemans J, Ghoos Y. The interdigestive motor complex of normal subjects and patients with bacterial overgrowth of the small intestine. J Clin Invest 1977; 59: 1158-66.

10 Kahn JJ, Jeffries GH, Sleiseger MH. Malabsorption in intestinal scleroderma. $N$ Engl J Med 1966; 274: 1339-44.

11 Salen G, Goldstein F, Wirts CW. Malabsorption in intestinal scleroderma. Relation to bacterial flora and treatment with antibiotics. Ann Intern Med 1966; 64: 834-41.

12 Kim YS, Spritz M, Blum M, Terz J, Sherlock P. The role of altered bile acid metabolism in the steatorrhea of experimental blind loop. J Clin Invest 1966; 45: 95662.

13 Hepner GW, Hofmann AF, Thomas PJ. Metabolism of steroid and amino acid moieties of conjugated bile acids in man. I cholyglycine. J Clin Invest 1972; 51 : 188997. 
14 Hepner GW, Hofmann AF, Thomas PJ. Metabolism of steroid and amino acid moieties of conjugated bile acids in man. II Glycine conjugated dihydroxy bile acids. $J$ Clin Invest 1972; 51: 1898-905.

15 Hepner GW, Sturmann JA, Hofmann AF, Thomas PJ. Metabolism of steroid and amino acid moieties of conjugated bile acids in man. III Cholyltaurine (taurocholic acid). J Clin Invest 1973; 52: 433-40.

16 Carey MC. The enterohepatic circulation. In: Arias I, Popper H, Schachter D, Schafritz DA, eds. The Liver: Biology and Pathophysiology. New York: Raven Press, 1982: 429-65.

17 Setchell KDR, Lawson AM, Blackstock EJ, Murphy GM. Diurnal changes in serum unconjugated bile acids in normal man. Gut 1982; 23: 637-42.

18 Paumgartner G, Mannes GA, Stellaard F. Serum bile acids and bile acid tolerance tests in liver disease. In: Barbara L, Dowling RH, Hofmann AF, Roda E, eds. Bile acids in gastroenterology. Lancaster: MTP Press Ltd, 1982: 217-22.

19 Setchell KDR, Worthington J. A rapid method for the quantitative extraction of bile acids and their conjugates from serum using commercially available reverse phase octadecylsilane bonded silica cartridges. Clin Chim Acta 1982; 125: 135-44.

20 Stellaard F, Sackmann M, Sauerbruch T, Paumgartner G. Simultaneous determination of cholic acid and chenodeoxycholic acid pool sizes and fractional turnover rates in human serum using ${ }^{13} \mathrm{C}$-labeled bile acids. J Lipid Res 1984; 25: 1313-9.

21 Setchell KDR, Matsui A. Serum bile acid analysis. Clin Chim Acta 1982; 127: 1-17.

22 Parmentier G, Eyssen H. Synthesis of the specific monosulfates of cholic acid. Steroids 1975; 26: 721-7.

23 Karlaganis G, Paumgartner G. Determination of bile acids in serum by capillary gas-liquid chromatography. Clin Chim Acta 1979; 92: 19-26.

24 Stellaard F, Paumgartner G. Measurement of isotope ratios in organic compounds at picomole quantities by capillary gas chromatography/quadrupole electron impact mass spectrometry. Biomed Mass Spectrom 1985; 12: 560-4.

25 Karlaganis G, Schwarzenbach RP, Paumgartner G. Analysis of serum bile acids by capillary gas-liquid chromatography - mass spectrometry. J Lipid Res 1980; 21: $377-85$.

26 Sauerbruch T, Wirsching R, Leisner B, Weinzierl M, Pfahler M, Paumgartner G. Esophageal function after sclerotherapy of bleeding varices. Scand J Gastroenterol 1982; 17: 745-51.

27 Hylemon PB, Stellwag EJ. Bile acid biotransformation rates of selected gram-positive and gram-negative intestinal anaerobic bacteria. Biochem Biophys Res Comm 1976; 69: 1088-94.

28 Angelin B, Björkhem I, Einarsson K, Ewerth S. Hepatic uptake of bile acids in man. Fasting and postprandial concentrations of individual bile acids in portal venous and systemic blood serum. J Clin Invest 1982; 70: 724-31.

29 Lewis B, Tabaqchali S, Panveliwalla D, Wootton IDP. Serum bile acids in the stagnant loop syndrome. Lancet 1969; I: 219-20.

30) Toskes PP, Gianella RA, Jervis HR, Rout WR, Takeuchi A. Small intestinal mucosal injury in the experimental blind loop syndrome. Light- and electronmicroscopic and histochemical studies. Gastroenterology 1975; 68: 1193-203.

31 Gracey M, Papadimitriou J, Burke V, Thomas J, Bower G. Effects on small intestinal function and structure induced by feeding a deconjugated bile salt. Gut 1973; 14: 519-28.

32 Ament ME, Shimoda SS, Saunders DR, Rubin CE. Pathogenesis of steatorrhea in three cases of small intestinal stasis syndrome. Gastroenterology 1972; 63: 728-47.

33 Cobden J, Rothwell J, Axon ATR, Dixon MF, Lintott DJ, Rowell NR. Small intestinal structure and passive permeability in systemic sclerosis. Gut 1980; 21 : 293-8.

34 Fromm H, Hofmann AF. Breath test for altered bileacid metabolism. Lancet 1971; ii: 621-5. 